Abstract 01-S04.05 Table 1 Prevalence and incidence data for East London students. (Note: Blood testing was declined by 2 students at 42 months and 4 youth and 54 months. Data were missing on vaginal intercourse for a further 3 students at 54 months)

\begin{tabular}{|c|c|c|c|c|c|c|c|c|}
\hline Gender & $\begin{array}{l}\text { No. of } \\
\text { evaluable } \\
\text { youth }\end{array}$ & $\begin{array}{l}\text { Mean age } \\
\text { in years (SD) }\end{array}$ & $\begin{array}{l}\text { Statistic } \\
\text { Prevalence }\end{array}$ & $\begin{array}{l}\text { Neisseria gonorrhoeae } \\
\%(95 \% \mathrm{CI})\end{array}$ & $\begin{array}{l}\text { Chlamydia trachomatis } \\
\%(95 \% \mathrm{CI})\end{array}$ & $\begin{array}{l}\text { Trichomonas vaginalis } \\
\%(95 \% \mathrm{Cl})\end{array}$ & $\begin{array}{l}\text { No. of } \\
\text { evaluable } \\
\text { youth }\end{array}$ & $\begin{array}{l}\text { Herpes simplex } \\
\text { type } 2 \\
\%(95 \% \text { CI) }\end{array}$ \\
\hline Male & 446 & $16.1(1.25)$ & 42 month prevalence & $0.90(0.26$ to 2.37$)$ & $3.14(1.83$ to 5.25$)$ & $0.90(0.26$ to 2.37$)$ & 444 & 3.15 (1.84 to 5.27$)$ \\
\hline Female & 513 & $15.5(1.17)$ & 42 month prevalence & 8.77 (6.60 to 11.56$)$ & $17.93(14.85$ to 21.50$)$ & 7.21 (5.26 to 9.81$)$ & 513 & $10.33(7.97$ to 13.28$)$ \\
\hline Male & 457 & $17.1(1.27)$ & 54 month prevalence & 1.75 (0.83 to 3.48$)$ & 7.22 (5.16 to 9.99 ) & $0.00(0.00$ to 1.00$)$ & 455 & 5.05 (3.36 to 7.50$)$ \\
\hline Female & 520 & $16.5(1.14)$ & $\begin{array}{l}54 \text { month prevalence } \\
\text { Incidence }\end{array}$ & $\begin{array}{l}7.69(5.68 \text { to } 10.33) \\
\text { new case } \\
\text { per } 1000(95 \% \mathrm{Cl})\end{array}$ & $\begin{array}{l}18.27(15.18 \text { to } 21.83) \\
\text { new case } \\
\text { per } 1000(95 \% \mathrm{CI})\end{array}$ & $\begin{array}{l}4.04(2.62 \text { to } 6.13) \\
\text { new case } \\
\text { per } 1000(95 \% \mathrm{Cl})\end{array}$ & 518 & $\begin{array}{l}15.64(12.75 \text { to } 19.03) \\
\text { new case } \\
\text { per } 1000(95 \% \mathrm{Cl})\end{array}$ \\
\hline Male & 434 & $17.1(1.24)$ & $\begin{array}{l}\text { Overall incidence } \\
\text { at } 54 \text { months }\end{array}$ & 18.4 (8.7 to 36.6 ) & 73.7 (52.4 to 102.5$)$ & $0.0(0.0$ to 10.6$)$ & 419 & 28.6 (15.9 to 49.9$)$ \\
\hline Female & 500 & $16.5(1.13)$ & $\begin{array}{l}\text { Overall incidence } \\
\text { at } 54 \text { months }\end{array}$ & 76.0 (55.6 to 102.8$)$ & 184.0 (152.4 to 220.4$)$ & $40.0(25.7$ to 61.3$)$ & 450 & 64.4 (44.9 to 91.3$)$ \\
\hline Male & 334 & $17.2(1.22)$ & $\begin{array}{l}\text { Incidence at } 54 \text { months } \\
\text { among those reporting } \\
\text { previous vaginal intercourse }\end{array}$ & $18.0(7.3$ to 39.6$)$ & 77.8 (53.3 to 112.0 ) & $0.0(0.0$ to 13.7$)$ & 322 & 18.6 (7.6 to 41.0$)$ \\
\hline Female & 331 & $16.6(1.06)$ & $\begin{array}{l}\text { Incidence at } 54 \text { months } \\
\text { among those reporting } \\
\text { previous vaginal intercourse }\end{array}$ & 108.8 (79.3 to 147.2$)$ & 244.7 (201.4 to 293.9 ) & 54.4 (34.2 to 84.8$)$ & 296 & $87.8(60.2$ to 126.0$)$ \\
\hline
\end{tabular}

curable STIs were treated. Females had a higher prevalence of all pathogens at both visits ( $\mathrm{p}<0.001$ for all, Abstract O1-S04.05 table 1). Overall annual incidence rates (per 1,000, 95\% CI), based on results of the 934 (96\%) students who attended the 42M/54M visits (934 urine, 931 serology tests), were substantially higher in females compared to males [males: GC 18.4 (8.7-36.6), CT 73.7 (52.4-102.5), TV 0.0 (0.0-10.6), HSV-2 28.6 (15.9-59.9); females: GC 76.0 (55.6-102.8), CT $184.0 \quad(152.7-220.4)$, TV 40.0 (25.7-61.3), HSV-2 64.4 (44.9-91.3)]. Incidence rates were also calculated for students (311 females, 66\%; 334 males, 77\%) who reported ever having had vaginal intercourse (Abstract O1-S04.05 table 1). Compared to overall rates, females had significantly higher rates for each STI (GC/CT, $p<0.001$; TV, $p=0.027$; HSV-2, $\mathrm{p}=0.015)$; this was not the case for males.

Conclusions This community-based screening study demonstrates an extremely high STI burden among youth in the Eastern Cape Province of South Africa.

\section{1-S04.06 PELVIC INFLAMMATORY DISEASE OCCURRING BETWEEN THE TIME OF TESTING AND TREATMENT FOR GONORRHOEA AND CHLAMYDIA}

\section{doi:10.1136/sextrans-2011-050109.24}

${ }^{1}$ W Risser, ${ }^{2} \mathrm{~J}$ Risser. ${ }^{1}$ University of Texas, Medical School, Houston, USA; ${ }^{2}$ University of Texas, School of Public Health, USA

Background We conducted a prospective study to confirm our impression that incarcerated adolescents sometimes developed pelvic inflammatory disease (PID) during the brief interval between testing and treatment for gonorrhoeal and chlamydial cervicitis.

Methods We performed the study at the Harris County Juvenile Detention Center, Texas, where PID in females is relatively common and where the prevalence of gonorrhoea and chlamydia infections is high. At the time of their mandated medical assessment, all incarcerated adolescents submitted first-catch urine samples for chlamydia and gonorrhoea testing. We used Gen-Probe NAAT assays. If at the time of testing a patient had symptoms suggestive of PID, we performed a bimanual pelvic examination and treated those who met the criteria for PID. For the diagnosis of PID, we used the criteria of the US Centers for Disease Control and Prevention: the presence of adnexal or cervical motion or uterine tenderness. The pelvic examinations were performed by one of three experienced physicians. For the patients who did not have PID at the time of testing, we re- assessed them when we learnt that their urine test was positive. The tests were run in batches by the city health department, so that a variable length of time elapsed between the day of testing and the day that we received test results. At re-assessment, patients received a PID diagnosis if they had lower abdominal pain and met the PID diagnostic criteria on bimanual pelvic examination.

Results We evaluated 99 subjects between 29 March 2010 and 27 December 2010. Their mean age was 15.8 (SD 1.1) years. Their race/ ethnicity was $43 \%$ black, $32 \%$ Hispanic, and $25 \%$ white; $74 \%$ had chlamydia, $14 \%$ gonorrhoea, and $12 \%$ both. The interval between testing and treatment ranged from 2 to 17 days; the mean (SD) was 7.5 (2.9) days. During this interval, 13 of 99 (13\%) developed lower abdominal pain and had bimanual pelvic examination findings that supported the diagnosis of PID. Of these 13, 10 (77\%) had chlamydia, $2(15 \%)$ had gonorrhoea, and $1(8 \%)$ had both infections. Time from initial urine testing to treatment for PID ranged from 7 to 15 days.

Conclusion In incarcerated adolescents infected with gonorrhoea and/or chlamydia, a surprisingly large proportion (13\%) developed PID during the brief period between testing and treatment.

\section{Epidemiology oral session 5: Vaginal infections 01-S05.01 THE EPIDEMIOLOGICAL ASSOCIATIONS OF BV CANDIDATE BACTERIA IN SEXUALLY EXPERIENCED AND INEXPERIENCED WOMEN WITH BV AND NORMAL VAGINAL FLORA}

doi:10.1136/sextrans-2011-050109.25

${ }^{1} \mathrm{C}$ Bradshaw, ${ }^{1} \mathrm{~K}$ Fethers, ${ }^{2} \mathrm{~F}$ Fowkes, ${ }^{3} \mathrm{~J}$ Twin, ${ }^{1} \mathrm{C}$ Fairley, ${ }^{3} \mathrm{~S}$ Garland, ${ }^{1} \mathrm{G}$ Fehler, ${ }^{1}$ A Morton, ${ }^{2} \mathrm{~J}$ Hocking, ${ }^{3} \mathrm{~S}$ Tabrizi. ${ }^{1}$ Melbourne Sexual Health Centre, Melbourne, Australia; ${ }^{2}$ University of Melbourne, Australia; ${ }^{3}$ Royal Women's Hospital, Australia

Background Several bacterial candidate organisms (COs) have recently been shown to be highly specific for $\mathrm{BV}$. The epidemiological profiles for these COs are unknown and no studies have examined $\mathrm{CO}$ in young sexually-inexperienced women, whether these COs are sexually-transmitted, or how they relate to specific sexual activities. Methods This study incorporates two study populations: The Female University Student Study which recruited women aged 17-21 years attending the University of Melbourne, and a sexuallyexperienced clinic population from Melbourne Sexual Health Centre. Participants completed a questionnaire addressing demographics and detailed sexual practices. Gram-stained vaginal smears 